\title{
火山灰茶園土壌における最適な呿素肥沃度の検索*
}

\author{
鹿児島県茶業試験場
}

烏山光昭 - 藤沜哲男 - 松元 順

\section{Research on the Optimum Nitrogen Fertility in \\ Volcanic Ash Tea Field}

\author{
By Mitsuaki Karasuyama, Tetsuo Fujishima and Jun Matsumoto \\ Kagoshima Tea Experiment Station
}

\section{1 まえがき}

最近，本県に扔いては多肥の傾向が強く，特に窒素肥 料は県で示された 標準施肥量をはるか水上回る量が施用 されている。しかるに堂素肥料は降雨により溶脱されや すく，とくに本県の年間降水量は約 $2200 \mathrm{~mm}$ であるた め，溶脱量もかなり多いものと推定される。そこで本県 に技いて，茶園に対する施肥は常に降水による窒菜の溶 脱を考慮し，単に施肥量のみではなく，土壤中に括ける 存在量つまり濃度について 留意する必要があると思われ る。

鍶者らは茶園に対する合理的施肥法を確立するために は，施肥時期抒よび施肥量を決定する際の指標をむず確

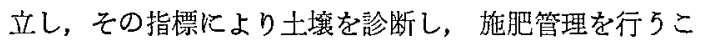
とが望むしいと考劣ている。そこで指標として土境中の 窒素肥沃度（乾士 $100 \mathrm{~g}$ に含まれる $\mathrm{NH}_{4}-\mathrm{N}$ と $\mathrm{NO}_{3}-\mathrm{N}$ の合計值を指し，以後“空素濃度”という）をとりあげ， 茶樹に対する最適值について検討しようとした。

茶樹に対する最適窒素濃度については，砂耕法等ては 明らかにされており, 窒素肥沃度と追肥窒素の吸収につ いてもポットで試験されている。茶園土壤に拉いてる， 収量化対する最適の空素擞度については中西ら゙が報告し ているが，煎茶品質に执よ深す窒素漂度の影響について は明らかでない。また，森苗は甘しょの生育，収量にお よ深す窒素浱度は生育時期により異なると報告して势 り, 茶樹も季節により生育, 養份吸収量は異なっている ため, 最適の窒装濃度は生育時期に上り異なると思われ る。そこで窒菜濃度を維持し，時期別に最適濃度を収 量，生葉执よび槊茶品質より検索しょうとした。

茶園土壌における最適の窒素濃度を時期別に求める試
験は，1974年より開始し 若干の知見が得られて抢り，本 報告では1977，1979年に実施した試験の結果をとりまと めて報告する。

\section{2 試 験 方 法}

\section{1 試 験 I}

多腐植質火山灰土（黑ボク）のやぶきた 9 年生茶園を 低試し，1区 $18 \mathrm{~m}^{2} の 4$ 連制で試験した。

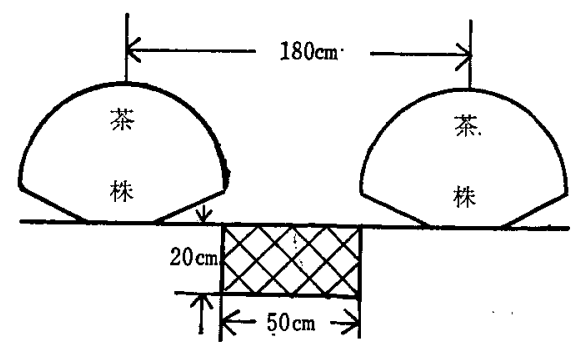

図 1 窒羕濃度維持の対象部位

窒素濃度の維持は図 1 亿示すよ 5 亿茶園のうね問 50 $\mathbf{c m}$, 深さ $20 \mathrm{~cm}$ の部位の土壤（以下5ね間土裹といら） を対象として，表 1 亿示す設計により 11月下旬〜2月中 旬の冬季を除き，全期閆の窒素濃度を乾土 $100 \mathrm{~g}$ あたり 12，24，36 mg に維持する区を設けた。別に貫行区とし て, 県標準施肥法に準じ窒菜 $50 \mathrm{~kg} / 10 \mathrm{a}$ を秋, 春捛よ び夏2 回の年間 4 回に分施する区を設けた。

施肥はあらかじめ処理区ごとにうね間土裹の容積重を 測定して执き，各区ごとに目標濃度となるよ5に施し た。さらにこの濃度を維持するために，約 2 週間に I回 の割合で 5 ね間土袞を採取して，土䖯中の $\mathrm{NH}_{4}-\mathrm{N}$ と $\mathrm{NO}_{3}-\mathrm{N}$ を定量し，目標涨度に対する窒素濃度の低下を

* 本報告の一部は昭和53，54年の日本土壌肥料学会・九州支部秋季例会て発表した。

$\dagger$ 池ケ谷賢次郎，平莑重郎，渡部育夫：茶技協請要，30，（Feb. 1977)。 
表 1 試験区名および処理方法（試験Ｉ）

\begin{tabular}{|c|c|c|c|}
\hline & 処 & 理 & j 法 \\
\hline 名 & 処理濃度 & $\begin{array}{l}\text { 浲 } \\
\text { 維持期間 } \\
\end{array}$ & 供試 肥 料 \\
\hline $\mathrm{N}-12$ & \multirow{3}{*}{$\begin{array}{l}\text { 乾 士 } \\
100 \mathrm{~g} \\
\text { 当たり }\end{array}$} & $\begin{array}{l}8 \text { 月中旬 } \\
\text { １1月中 }\end{array}$ & \multirow{4}{*}{ 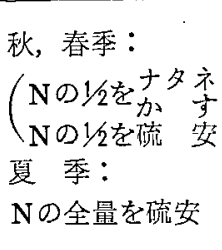 } \\
\hline $\mathrm{N}-24$ & & 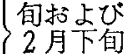 & \\
\hline $\mathrm{N}-36$ & & 䏌 7 月下 & \\
\hline 慣 行 & \multicolumn{2}{|c|}{ N50kgを 4 回に分拖する } & \\
\hline
\end{tabular}

表 2 試験区名怙よび処理方法（試験 II）

\begin{tabular}{|c|c|c|c|}
\hline 処理 & 時 期 別 & $\mathrm{N}$ 祳 度 & \\
\hline 式馱 & $\begin{array}{l}8 \text { 月下旬 } \\
\text { 〜11月旬 }\end{array}$ & $\begin{array}{l}2 \text { 月下自 } \\
\sim 4 \text { 旬 } \\
\end{array}$ & 肥料 \\
\hline $\mathrm{N} 12-12$ & \multirow{3}{*}{$\int /$ 乾士 } & \multirow{3}{*}{$\begin{array}{l}12 \mathrm{mg} / \text { 乾土 } \\
100 \mathrm{~g}\end{array}$} & \multirow{6}{*}{ 硫安 } \\
\hline N24-12 & & & \\
\hline N36-12 & & & \\
\hline $\mathrm{N} 12-24$ & \multirow{3}{*}{ / / 乾土 } & \multirow{3}{*}{$24 \mathrm{mg} /$ 乾土 $_{100 \mathrm{~g}}$} & \\
\hline N24-24 & & & \\
\hline N36-24 & & & \\
\hline
\end{tabular}

補正した。定量法は $\mathrm{NH}_{4}-\mathrm{N}$ は水蒸気蒸留法, $\mathrm{NO}_{3}-\mathrm{N}$ はフェノール硫酸法を用いた。

窒素肥料として秋季，春季はナタネかす（ $\mathrm{N}$ 含有率は ，5\%）之硫安，夏季は硫安だけを供試し，施肥を均一に

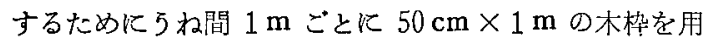
いて施用した。リン酸，カリは各処理区とも秋季，春季 にそれぞれ $12 \mathrm{~kg} / 10 \mathrm{a}$ 施用した。

各茶期の収量, 煎茶品質を調査し, 茶葉の全窒素含有 率は茶試化学研究空の方法で分析した。

\section{2 試 験 II}

茶樹の生育相に応じて時期別に窒素濃度をかえて試験 を行った。

多腐植質火山灰土（黒ボク）のやぶきた 9 年生茶園を 供試し秋季，春季にそれぞれ 䇪素濃度をが，一香茶に
対する影響を調查した。試験区は 1 区 $18 \mathrm{~m}^{2}$ の 3 連制と した。窒菜濃度調査の対象とする万被土壤の部位は試 験（と同様とし，処理区は表 2 に示すよ5に秋季（8月 下旬〜11月中旬）の窒素漕度を乾土 $100 \mathrm{~g}$ あたり $12 ， 24$ $36 \mathrm{mg} の 3$ 段階, 春季 (2 月下旬 4 月下旬) を 12,24 , $\mathrm{mg}$ の 2 段階とした。

窒菜肥料として秋季，春季ともに硫案たけを供試した ことと， $\mathrm{NO}_{3}-\mathrm{N}$ をオンメータで定量した活か外試駼 Iに準じた。

一番茶の生充, 収量, 新芽の窒菜收㩔量, 煎茶品質お よび茶葉中の化学成分について調查した。

\section{3 結果および考察}

\section{1 試 験 I}

(1) 窒素の施用量

容棈重 $(0.72)$ 加算出すると, 5和間 $50 \mathrm{~cm}$, 深さ $20 \mathrm{~cm}$ の土壤の窒素荟度を乾土 $100 \mathrm{~g}$ あたり $1 \mathrm{mg}$ 高め るには $10 \mathrm{a}$ あたり窒素成分で $0.4 \mathrm{~kg}$ が必要であった。

窒素莀度を維持する区では，処理期間中約 2 週䦓に 1 回，年間では 16回処理溉度をチェックした。その結果， 窒菜濃度を維持するために必要な施肥回数は表 3 亿示す よ5に 7 回となり, 残り 9 回の測定では窒素濃度の低下 は少なく，追肥の必要はなかった。10a あたりの年間施 用量は慣行区に比較して N-12mg 区では少なかったが， $\mathrm{N}-24 \mathrm{mg}$ 区では $62.1 \mathrm{~kg}, \mathrm{~N}-36 \mathrm{mg}$ 区では $94.7 \mathrm{~kg}$ で慣 行区の約 2 倍量であった。

\section{(2) 収量}

慣行区の収量を 100 としたときの窒索濃度維持区の収 量指数を図 2 に示した。

一番茶の収量は慣行区に比較して，N-12mg 区では少 なく，空素賑度を $24 \mathrm{mg}$ に高めることにより增加した がささらに $36 \mathrm{mg}$ に高めても N-24mg 区と大差がなか った。二番茶の $\mathrm{N}-12 \mathrm{mg}$ 区は慣行区と大差なく，24mg に高めることにより增収したが，さらに $36 \mathrm{mg}$ に高めて る収量の増加はわずかであった。三番茶の収量は慣行区 に比較し， N-12 mg 区では少なかったが，窒素濃度を $36 \mathrm{mg}$ まで高めるのに伴って增収した。

表 3 試験 Iにおるおる窒素の施用時期および施肥量 $(\mathrm{kg} / 10 \mathrm{a})$

\begin{tabular}{|c|c|c|c|c|c|c|c|c|c|c|}
\hline \multirow{2}{*}{ 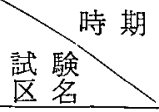 } & \multirow{2}{*}{$\frac{\text { 秋 }}{8 / 10}$} & \multirow{2}{*}{$\frac{\text { 季 }}{9 / 20}$} & \multirow{2}{*}{$\frac{\text { 春 }}{2 / 22}$} & \multirow{2}{*}{$\begin{array}{r}\text { 季 } \\
4 / 14\end{array}$} & \multicolumn{2}{|r|}{ 夏 } & \multicolumn{3}{|c|}{ 季 } & \multirow{2}{*}{ 年間合計 } \\
\hline & & & & & $5 / 3$ & $5 / 13$ & $6 / 8$ & $6 / 20$ & $6 / 28$ & \\
\hline $\mathrm{N}-12$ & 4.8 & 4.8 & 4.8 & 4.8 & - & 2.8 & 3.1 & - & 4.8 & 29.9 \\
\hline$N-24$ & 9.6 & 9.6 & 9.6 & 9.6 & - & 6.7 & 7.4 & - & 9.6 & 62.1 \\
\hline$N-36$ & 14.4 & 14.4 & 14.4 & 14.4 & - & 10.7 & 12.0 & - & 14.4 & 94.7 \\
\hline 慣 行 & 15 & - & 15 & - & 10 & - & - & 10 & - & 50.0 \\
\hline
\end{tabular}




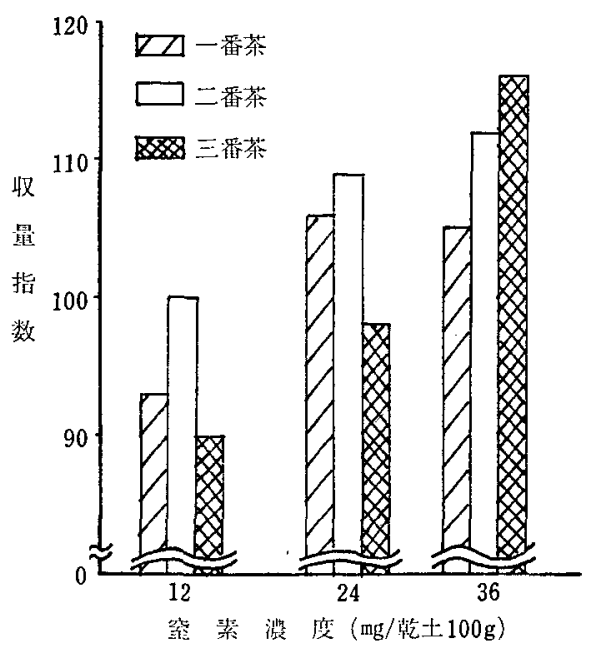

図2 収量指数

以上の結果から，窒素濃度を $24 \mathrm{mg}$ 以上に維持するこ とは慣行施肥法に比へ，収量をいくぶん增加させると思

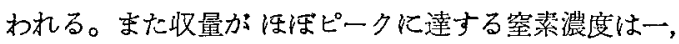
二番茶で $\mathrm{N}-24 \mathrm{mg}$ 区，三番茶では $\mathrm{N}-36 \mathrm{mg}$ 区であり，収 量に対する最適の窒素濃度区は茶期によって異なった。 このことは, 夏茶期は窒菜の栄莨状態が劣り，窒菜濃 度を高めた効果が三番茶で顕著に現れたためと考兄ら れる。

(3) 煎茶品質

煎茶品質についての総合評価を図 3 に示した。

窒素濃度を維持した区ではいずれる慣行区に比較し， 各茶期ともに煎茶品質はすぐれる傾问を示した。一番茶 では窒素濃度を.12 mg から $24 \mathrm{mg}$ に高めることにより， 煎茶品質は向上したが，さらに $36 \mathrm{mg}$ に高めても $\mathrm{N}-24$ $\mathrm{mg}$ 区と大差なかった。一方，二，三番茶ては N-36 mg 区が最もすぐれ，䓨素濃度が高い活ど煎茶品質はすぐれ る傾向を示した。

以上の結果から，煎茶品犋は窒菜濃度を維持すること により向上すると思われる。また最適の窒菜濃度区は一 番茶では $\mathrm{N}-24 \mathrm{mg}$ 区，三，三番茶では $\mathrm{N}-36 \mathrm{mg}$ 区であ り，煎茶品質に対する最適濃度は収量々同様，茶期によ

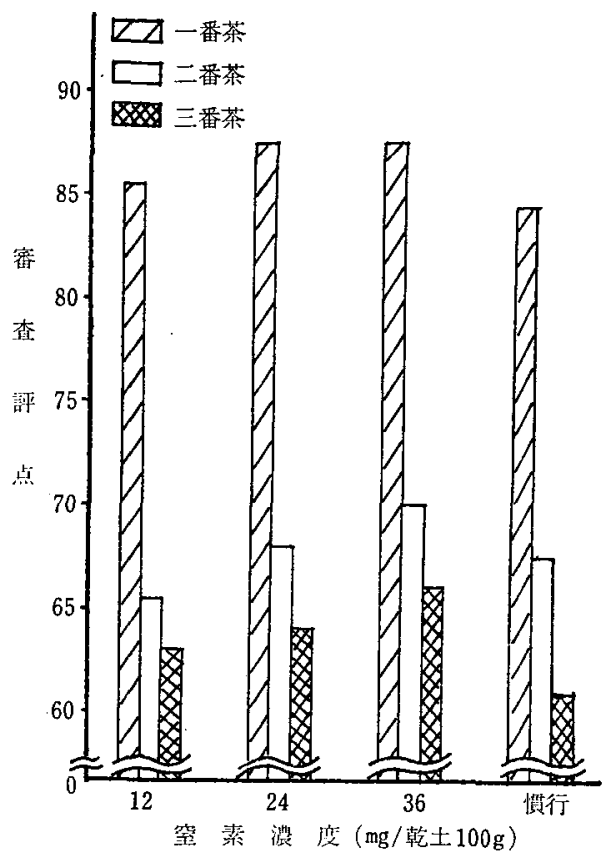

図 3 煎茶品質

って異なり，二，三番茶期では高い漂らが良好と考えら れる。

(4) 茶葉中の全窒素含有率

各茶期の摘採日に括ける 新芽（一芯三葉）および成萂 の全窒素含有率を表 4 に示した。

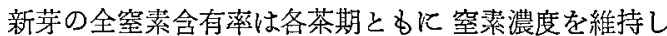
た区が高く，しかも窒素浱度の高い区医ど多い傾向を示 した。一方成葉に拁いては，一番茶では N-24 mg 区と N-36 mg 区の 全窒素合有率は変らず，二番茶では N$36 \mathrm{mg}$ 区が高く，三蕃茶では窒素濃度が高まるのに伴っ て全䆓素含有率も高まる傾向を示した。このことから成 葉では，窒素浱度を高めた効果は一番茶より二,三番茶 のほうが高いるのと考允られる。

（5）慣行区の無機態窒素濃度の推移

慣行区のう和間土壤（深さ $20 \mathrm{~cm}$ ）に扰ける 無機態窒 素濃度の推移を図 4 亿示した。

表 4. 茶樂中の全室素含有率（乾物\%)

\begin{tabular}{|c|c|c|c|c|c|c|c|c|c|c|c|c|}
\hline 部 茶期 & \multicolumn{4}{|c|}{ 一番茶（4月21日） } & \multicolumn{4}{|c|}{ 二番茶（6月13日） } & \multicolumn{4}{|c|}{ 三番茶（7月18日） } \\
\hline 試験区名 & 新 & 芽 & 成 & 葉 & 新 & 芽 & 成 & 葉 & 新 & 芽 & 成 & 葉 \\
\hline $\mathrm{N}-12$ & \multicolumn{2}{|c|}{5.87} & \multicolumn{2}{|c|}{3.08} & \multicolumn{2}{|c|}{4.24} & \multicolumn{2}{|c|}{3.25} & \multicolumn{2}{|c|}{4.44} & \multicolumn{2}{|c|}{3.52} \\
\hline $\mathrm{N}-24$ & \multicolumn{2}{|c|}{6.05} & \multicolumn{2}{|c|}{3.31} & \multicolumn{2}{|c|}{4.15} & \multicolumn{2}{|c|}{3.26} & \multicolumn{2}{|c|}{4.61} & \multicolumn{2}{|c|}{3.70} \\
\hline $\mathrm{N}-36$ & \multicolumn{2}{|c|}{6.14} & \multicolumn{2}{|c|}{3.31} & \multicolumn{2}{|c|}{4.31} & \multicolumn{2}{|c|}{3.43} & & & \multicolumn{2}{|c|}{3.85} \\
\hline 慣 行 & \multicolumn{2}{|c|}{5.79} & & & \multicolumn{2}{|c|}{4.20} & \multicolumn{2}{|c|}{3.24} & & & \multicolumn{2}{|c|}{3.64} \\
\hline
\end{tabular}




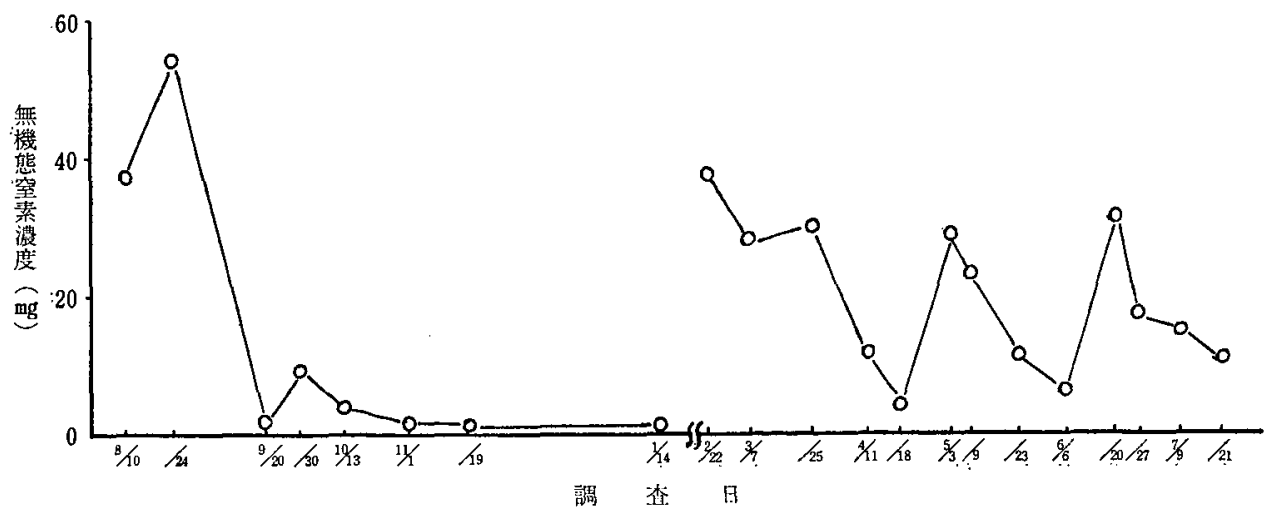

図4 慣行区に扣ける無機態窒素濃度の推移

慣行区の施肥時の窒素濃度は理諭值とし，対象部位の 乾土重と施肥量から算出した結果, $15 \mathrm{~kg} / 10 \mathrm{a}$ 施用した 秋肥，春肥により乾土 $100 \mathrm{~g}$ あたり $37.5 \mathrm{mg}, 10 \mathrm{~kg} / 10 \mathrm{a}$ 施用した夏肥(1)，(2)では $25 \mathrm{mg}$ の窒素浱度が施肥前より る高められた。

窒素濃度の推移については, 秋肥 2 週間後（8月24日） から9月20日までに窒菜濃度は著しく低下し，9月20日 から翌年の 1 月14日さでは低い案素濃度で推移した。春 肥（2 月22日）から一番茶摘採の約 1 力月前（3月25日） までの窒素濃度は高く推移し，以後 4 月18日まで急激に 低下した。夏肥(1)（5月3日）直後は高まったが以後低 下し, 二番茶摘採 1 週間前（6月6日）では乾土 $100 \mathrm{~g}$ あたり $6.5 \mathrm{mg} て ゙$ 施肥時の 22\%であった。夏肥(2)（向月 20日）以後の窒䒺濃度の低下は夏肥 (1)以後よりも綬慢 で，三番茶摘採の 3 日後（7月21日）において $10.7 \mathrm{mg}$ で施肥時の 40\%であった。な技窒素濃度の経持区におい ても窒素濃度は低下したが，補正したため活深目標濃度 に維持できた。

以上の結果，慣行区の一番茶の収量，品質が $\mathrm{N}-24 \mathrm{mg}$ 区，N-36 mg 区に比へて劣った原因としては，9月20 日以降すなわち秋茅の充実期化括いて 空菜濃度がきわめ て低かったことが考えられる。次に慣行区は夏肥時の窒 素濃度が注深同じである $\mathrm{N}-24 \mathrm{mg}$ 区に比べて二，三番 茶の収量，品質が劣ったが，これは夏季における窒素濃 度の低下が大さかったためと考点られる。また二，三番 茶では N-36 mg 区がすぐれることから，夏季に执いて は窒索濃度を維持するだけでなく，夏肥時の窒素濃度を 慣行区よりる高める必要があると考兄られる。

(6) 最適な窒素濃度の検索

収量，煎茶品質拈よび茶葉の全宔素含有率の調査結果 からみて，最噈と考学られる濃度区は一番茶では N-24 $\mathrm{mg}$ 区，二，三番茶では $\mathrm{N}-36 \mathrm{mg}$ 区であった。しかし 処理区の窒菜濃度は施肥時の目標值であり，処理期間に
おける実質的な窒素濃度とは異なると考えられる。そこ で処理期間に拈ける窒菜濃度の平均值を算出し，これを 最適な窒菜濃度とした。平均值は下記の式で求め, 表 5 に示した。

平均値 $=\{\{a(A+B) / 2\}+\{b(C+D) / 2\}+\{\cdots \cdot\}]$

$$
/ a+b+\cdots
$$

注 1 A , B , C , D , ‥ 窒素濃度の測定值

注 $2 a, b, \cdots$ 测定の關隔日数

注 3 窒素濃度の補正を行った場合は，土壤分析を 行わず理論值を施肥時の窒菜濃度とみなした。

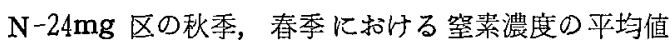
は，8月10日〜11月 19日では $20.9 \mathrm{mg} ， 2$ 月22日〜 4 月 18日では $17.8 \mathrm{mg}$ であるため，一番茶に対する秋，春季 の最適な窒素湜度は乾土 $100 \mathrm{~g}$ あたり $20 \mathrm{mg}$ 程度と推測 される。 N-36 mg 区では 4 月18日〜 7 月 21 日の平均值 は29.5 mg であり，1978年の試験では， 5 月13日〜 7月 24日の最適の窒素濃度は 30〜 40 mg と考えられたため， 夏季に括ける最適の窒索濃度は乾土 $100 \mathrm{~g}$ あたり $30 \mathrm{mg}$ 程度と推測される。しかし二, 三番茶に就いては秋肥， 春肥からの窒素る含をれているため, 夏季の窒菜濃度 だけでく秋季，春季の窒素濃度の影響もらけることが 推察されるのでこの点についてる考慮しなければならな w。

表 5 窒素濃度の平均值 $(\mathrm{mg} /$ 乾土 $100 \mathrm{~g})$

\begin{tabular}{r|r|r|r}
\hline 期 & 䦭 & $8 / 10 \sim 11 / 19$ & \multicolumn{2}{|c}{$2 / 22 \sim 4 / 18 \sim 7 / 21$} \\
試験区名 & 13.3 & 10.7 & 9.1 \\
N-12 & 20.9 & 17.8 & 19.2 \\
N-24 & 29.6 & 24.8 & 29.5 \\
N-36 & 29.8 & \\
\hline
\end{tabular}

$†$ 鹿児島県茶試: 昭和53年度試験成績書 (土肥), pp. 16 29 (1978). 


\section{2 試 験 II}

(1)窒菜の施用量

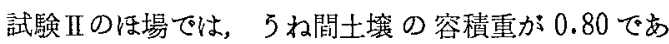
ったため5朴間 $50 \mathrm{~cm}$, 深さ $20 \mathrm{~cm}$ の土塨の窒菜莀度を 乾土 $100 \mathrm{~g}$ あたり $1 \mathrm{mg}$ 高めるには, $10 \mathrm{a}$ あたり空菜成 分として $0.44 \mathrm{~kg}$ 必要であった。

各区は約 2 週間に 1 回，すなわち 処理期間（8 月22日 〜11月21日拉よび2月19日〜 4 月23日)では 10回処理濃 度をチェックした。その結果，窒素莀度を維持するため に必要な施肥回数は，最子窒菜濃度の高い N $36-24 \mathrm{mg}$ 区で6回，N 12-12mg 区，N 12-24mg 区は3回で，そ の施肥時期竹よび施肥量については表 6 のと拈りであっ た。

試験開始前（8月21日）の土袞中に括ける 無機態窒菜 濃度は $24.5 \mathrm{mg}$ であったため，8 月 22 日は秋 $36 \mathrm{mg}$ に 維持与る区の及施肥し，9月19日以降は表6亿示すと招

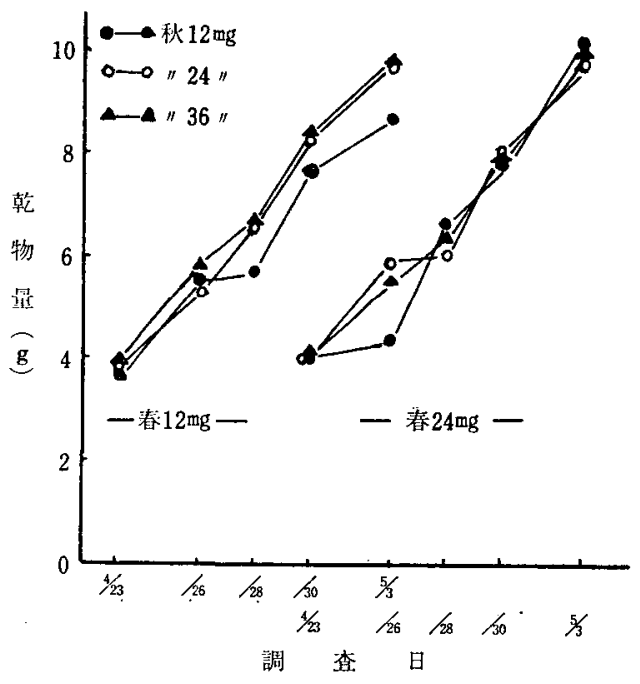

図 5 新芽 100 当たり乾物重の推移
りに処理した。窒甞濃度を維持するために必要な窒索量

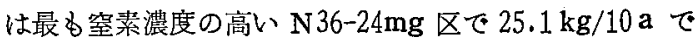
あった。

(2) 生 云, 収量

一番茶摘採の 8 日前から摘埰 2 日後までの期間に打い て，新芽 100 本あたりの乾物重の推移を図 5 に示した。 乾物重は N12-12 mg 区で最す少なく推移し，この傾 向は新芽が伸びるに従い顕著に認められた。これに対し 秋季なたは春季いずれかの窒素濃度を $24 \mathrm{mg}$ に高めるこ とにより乾物重は增加したが，秋季の濃度をさらに 36 $\mathrm{mg}$ 汇高めてる $24 \mathrm{mg}$ に維持した区と大差がなかった。

一番茶の収量を表 7 に示した。秋季の窒素濃度を 12 $\mathrm{mg}$ から $36 \mathrm{mg}$ まで高めても一番茶の収量は堌加せず, 春季の 窒素濃度を $12 \mathrm{mg}$ から $24 \mathrm{mg}$ に高めても収量は ほとんぞ增加しなかった。

N12-12 mg 区は他区に比べて乾物重が劣ったにるか かわらず，収量では大差がなかったことから，室素濃度 の高い区にくらべ较数型になったのではないかと推察さ れる。

秋季拉よび春季の窒素濃度が $12 \mathrm{mg}$ の場合に一番茶の 生育が少る点は試験 I の結果と同様であった。しかし試 験 Iでは秋季, 春季の窒素濃度をともに $24 \mathrm{mg}$ に高める ことにより収量は増加したのに比べ，試験Iでは秋季， 春季のいずれかの時期の窒菜濃度を $24 \mathrm{mg}$ に高めること によって生育は向上した。これらのことから一番茶の生 育, 収量に対しては秋季, 春季の窒菜濃度をともに 24 mg に高める必要はないるのと考允られる。

(3) 窒菜収奪量

新芽の乾物重に全窒萃含有摔を乘じて 窒素収奪量を算 出した。一畄茶摘採の 8 日前から摘操の 2 日後をでの期 間において，新芽 100 本あたりの窒素収奪量の推移を図 6に示した。

表 6 武験Iにおおる窒坛の施用時期および施用量 $(\mathrm{kg} / 10 \mathrm{a})$

\begin{tabular}{|c|c|c|c|c|c|c|c|}
\hline \multirow{2}{*}{ 試験区名 } & \multicolumn{3}{|c|}{ 秋 } & & \multicolumn{2}{|l|}{ 春 } & \multirow{2}{*}{ 合 } \\
\hline & $8 / 22$ & $9 / 19$ & $10 / 4$ & $11 / 2$ & $2 / 19$ & $4 / 9$ & \\
\hline $\mathrm{N} 12-12$ & - & - & - & 1.3 & 4.4 & 3.7 & 9.4 \\
\hline N24-12 & - & 2.8 & 1.0 & 3.0 & 3.2 & 3.7 & 13.7 \\
\hline N36-12 & 4.8 & 3.2 & 4.0 & 2.7 & 1.2 & 3.7 & 19.6 \\
\hline N12-24 & - & - & - & 1.3 & 9.2 & 4.4 & 14.9 \\
\hline $\mathrm{N} 24-24$ & 二 & 2.8 & 1.0 & 3.0 & 8.0 & 4.4 & 19.2 \\
\hline N $36-24$ & 4.8 & 3.2 & 4.0 & 2.7 & 6.0 & 4.4 & 25.1 \\
\hline
\end{tabular}

$\dagger$ 鹿児䈱県茶試：昭和54年度試験成績著（土肥），pp 18３3 (1979)， 
表7一番茶 0 収量

\begin{tabular}{c|c|c}
\hline \multirow{2}{*}{ 試験 区 名 } & \multicolumn{2}{|c}{ 収 } \\
\cline { 2 - 3 } & $\mathrm{kg} / 10 \mathrm{a}$ & 指 \\
\hline N 12-12 & 529 & 100 \\
N 24-12 & 546 & 103 \\
N 36-12 & 523 & 99 \\
\hline N 12-24 & 540 & 102 \\
N 24-24 & 553 & 105 \\
N 36-24 & 548 & 104 \\
\hline
\end{tabular}

新芽 100 本当たりの窒素収奪量は $\mathrm{N} 12-12 \mathrm{mg}$ 区で最 す少なかった。これに対して秋季むたは春季の窒䒺浱度 を $24 \mathrm{mg}$ に高めることにより, 窒菜收奪量は增加し，特 に春季に高めた区では著しく增加した。しかし秋季の窒 素濃度を $36 \mathrm{mg}$ に高めても窐菜収奪量は増加しなかっ た。

一番茶の新芽に括ける堂素收奪量は，秋季の窒素濃度 に関係なく春季を $24 \mathrm{mg}$ に高めた区で多かったため，一
番茶は秋季より春季の窒菜浱度に 影響されるものと考兄 られる。

(4) 煎茶品質

一番茶の煎茶品質について官能審查した結果を表 8 K 示した。

N12-12 mg 区の香気，滋味は他区よりも劣り，総合評 点る低かった。これに対して秋季の窒蒵濃度を $24 \mathrm{mg}$ に 高めることにより香気，滋味はとすに向上したが，さら に $36 \mathrm{mg}$ に高めても，内容品質は $24 \mathrm{mg}$ に維持した区 と大差がなかった。一方春季の窒素濃度を $24 \mathrm{mg}$ に高め た場合には，内容品質はさらに向上し，秋季の窒菜濃度 に関係なく煎茶品貿はすぐれた。窒素濃度を高める時期 について N24-12 mg 区と N12-24 mg 区で比較すると， 春季に高めた場合のほうが特に香気，滋味がすぐれる傾 向が認められた。

以上の結果から，一番茶の煎茶品貶は秋季上りも春季 の窒素莀度に影響されるものと推察されるため, 春季の 空素濃度を $24 \mathrm{mg}$ に高めるのが妥当であると考党られ る。

(5) 茶葉化学成分

秋肥から一番茶の萠芽期（4月 3 日）までの成葉の全

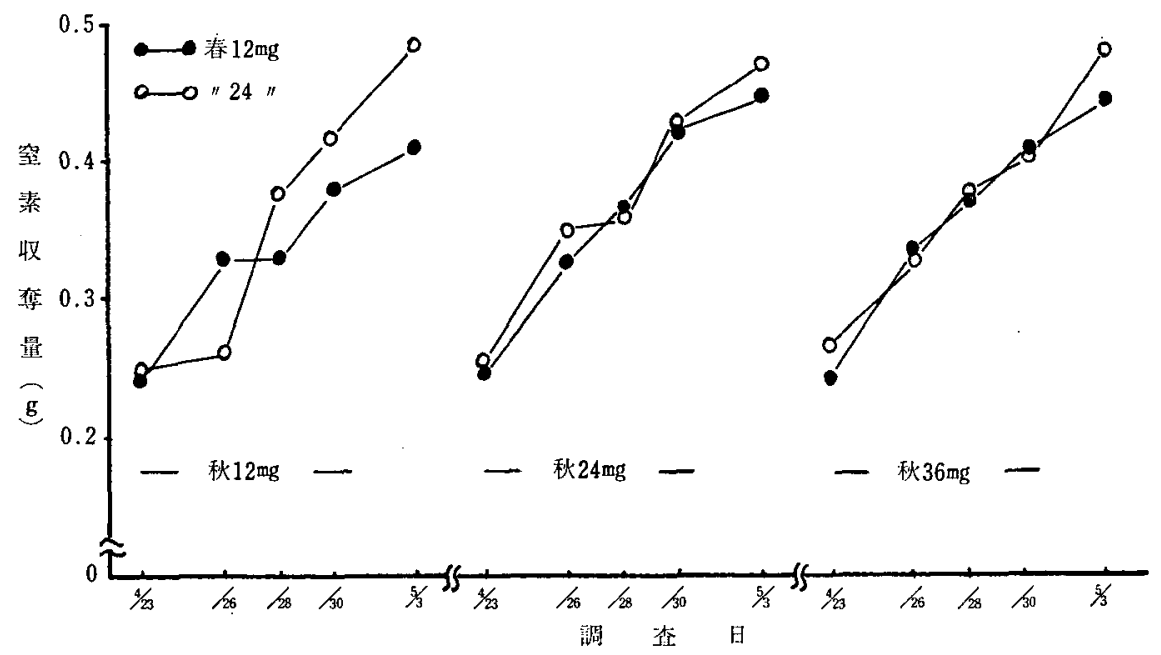

园6新芽100本当たりの窒素収奪星の推移

表 8 一番茶 $の$ 煎菉品質

\begin{tabular}{c|c|c|c|c|c|c|c}
\hline 試験区名 & 形 状 & 色 沢 & 香 気 & 水 色 & 滋 味 & 内容計 & 䋓 \\
\hline N 12-12 & 16.0 & 16.5 & 15.5 & 16.5 & 15.5 & 47.5 & 80.0 \\
N 24-12 & 15.5 & 16.5 & 16.5 & 16.5 & 16.5 & 49.5 & 81.5 \\
N 36-12 & 15.5 & 15.5 & 17.0 & 16.5 & 17.0 & 50.5 & 81.5 \\
\hline N 12-24 & 15.5 & 16.5 & 17.0 & 15.5 & 17.5 & 50.0 & 82.0 \\
N 24-24 & 15.5 & 16.0 & 17.5 & 16.0 & 17.5 & 51.0 & 82.5 \\
N 36-24 & 15.5 & 16.0 & 16.0 & 15.5 & 18.0 & 49.5 & 81.0 \\
\hline
\end{tabular}


窒素含有率の推移を表 9 に示した。

成葉の全窒素含有率は秋肥以後高まり，11月6日で最 も高い值を示した。その後は徐々に低下し，4月 3 日で は侵す低くなった。秋季の窒素濃度を $12 \mathrm{mg}$ 亿維持した 区では，2月14日の成葉の全窒素含有率は他区に比べて 低いが，4月 3 日では $24 \mathrm{mg} ， 36 \mathrm{mg}$ に維持した区と大 差ないため，秋季の窒素濃度は成葉の全窒素含有率に対 してあまり影響しないものと考兄られる。これは窒素 濃度々ともに, 秋肥の茶樹浪対する器官別分布割合は地 下部に多く，成葉への寄与率が低以ためと推定される。

一番茶の萠芽期より摘採日までの成葉の全窒菜含有率 の推移を図 7 に示した。

成葉の全窒素含有率は袴田らが報告したように, 新芽 の開葉とともに急激に低下した。秋季の空素濃度と成葉 の全窒素含有率との間には明らかな傾向は認められなか つた。春季の窒素濃度を $24 \mathrm{mg}$ に維持した区は $12 \mathrm{mg}$ 区 に比べて，秋季の窒素浱度に関係なく開葉にともなら全 窒崇含有率の低下注綵慢であった。

一番茶の新芽の全空菜含有率，可溶阯空素およびタン ニンの含有率を表 10 に示した。

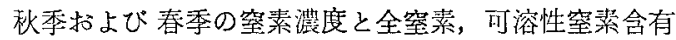
率との關には明らかな 傾向は認められなかった。タンニ ン含有率は 堂素濃度の最马高い N 36-24 mg 区でやや低 く，春季の濃度を $12 \mathrm{mg}$ より $24 \mathrm{mg}$ に高めることによ りわずか怟下する傾向があり，これは 1978年の試験で

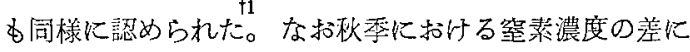
よる影響は認められなかった。

以上の結果から，春季の窒素濃度を高めることにより 成䐑の窒素レベルは高く保たれ，新芽のタンニン含有率 怟下するものと考完られる。

(5) 最適な窑素濃度の梌索

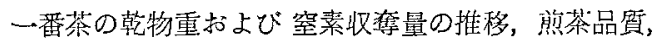
茶葉分析の結果から，一番茶に対しては秋季よりも春季 の窑素濃度を高めた効果が高く，最適と考克られる処理 区は N12-24 mg 区で岕った。

最適な窒素濃度は試験 Iに準じ， 処理期間に打ける窒菜濃度の平均値 として表11反示した。処理前の窒素 濃度が高かったため秋季の空菜髥度 の平均値は, 試験開始直後と9月下 甸以降の時期彷分けて算出した。

N 12-24 mg 区の平均値は 8 月 22 日〜9月18日では $21.9 \mathrm{mg}, 9$ 月 18 日〜11月21日では $13.5 \mathrm{mg}, 2$ 月 19 日〜4月23日では $19.0 \mathrm{mg}$ であっ た。1978年に実施した同一設計の試 験です N12-24 mg 区がすぐれ，窒
表 9 秋肥以後に括ける成葉の全窒菜含有率(乾物\%)

\begin{tabular}{c|c|c|c|c|c}
\hline 処理濃度 & $9 / 21$ & $11 / 6$ & $12 / 21$ & $2 / 14$ & $4 / 3$ \\
\hline 秋季 12mg 区 & & 4.20 & 3.74 & 3.41 & 3.52 \\
" 24mg 区 & 3.45 & 4.03 & 3.71 & 3.68 & 3.57 \\
" 36mg 区 & 3.50 & 4.09 & 3.73 & 3.60 & 3.51 \\
\hline
\end{tabular}

注） $4 / 3$ の数值は春季 $24 \mathrm{mg}$ 区のもの

表10 新芽の化学成分 (乾物只)

\begin{tabular}{l|c|c|c}
\hline 試験区名 & 全 窒 蒵 & 可溶性窒素 & タンニン \\
\hline N 12-12 & 5.79 & 1.77 & 14.5 \\
N 24-12 & 5.93 & 1.79 & 14.5 \\
N 36-12 & 5.82 & 1.81 & 14.5 \\
\hline N 12-24 & 5.79 & 1.88 & 14.0 \\
N 24-24 & 5.75 & 1.80 & 14.2 \\
N 36-24 & 5.79 & 1.84 & 13.7 \\
\hline
\end{tabular}

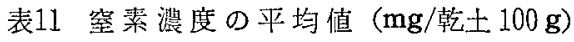

\begin{tabular}{c|c|c|c}
\hline 試験区名 & \multicolumn{2}{|c|}{$8 / 22 \sim 9 / 18 \sim 11 / 21$} & $2 / 19 \sim 4 / 23$ \\
\hline N 12-12 & \multirow{2}{*}{21.9} & $\begin{array}{l}13.5 \\
20.5\end{array}$ & \\
N 24-12 & & 3.4 \\
N 36-12 & 32.6 & 30.7 & \\
\hline N 12-24 & \multirow{2}{*}{21.9} & 13.5 & \\
N 24-24 & & 20.5 & \multirow{2}{*}{19.0} \\
N 36-24 & 32.6 & 30.7 & \\
\hline
\end{tabular}

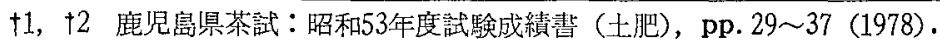


弥濃度の平均値は 8 月22日〜11月21日では $11.4 \mathrm{mg}, 2$ 月17日〜 5 月 1 日では $23.8 \mathrm{mg}$ であったことから，一番 茶に対する最適の窒素瀳度は，9月下旬～11月中旬の秋 芽の充実期では乾土 $100 \mathrm{~g}$. あたり $12 \mathrm{mg}$ 程度, 春肥から 一番茶摘採までは $22 \mathrm{mg}$ 程度と推測される。

試験 Iでは一番茶に対する秋，春季の最適窒素濃度は $20 \mathrm{mg}$ 程度と推測したが, 試験 II において秋季と春季の 最適窒素浱度は異なるとい5結果を得ており，一番茶に 対しては秋季と春季に分けて 最適空素濃度を決定するの が望をしいと考えられる。

\section{4 摘 要}

11月下旬 2 月中旬を除き 秋肥後翌年の三番茶むでの 期間に打いて，土裹中の窒素浱度を 3 段階にか兑て，茶 園土壤に招ける最適の窒素浱度を検索した。

また秋季，春季の土壤中の窒素濃度をそれぞれ数段階 にかえて，一蓄茶に対する秋季，春季の最適の窒菜濃度 を検索した。その結果は次のよ5に要約される。

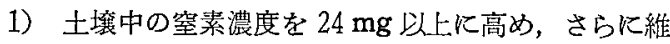
持した区は，慣行施肥区に比べて多収で，新芽の全窒素 含有率は高く，前茶品質もすぐれた。

2）最適の窒素濃度区は一番茶では N-24 mg 区，二， 三番茶では $\mathrm{N}-36 \mathrm{mg}$ 区であり，最適の 窒菜濃度は時期 によって異なり, 秋季, 春季よりも夏季の潘らが高いも のと䓔光られた。

3）秋季，春季の窒素碾度が $12 \mathrm{mg}$ の場合には一番茶 の生育, 収量, 窒素収奪量拉よび 煎茶品質はいずれる劣 った。一番茶の乾物重は秋季，春季いずれかの窑素浱度 を $24 \mathrm{mg}$ に高めることにより增加したが，窒素収奪量拉 よび煎茶品俱は秋季よりす春季の室素濃度に影響され， 春季を $24 \mathrm{mg}$ に高めることによって窒素収奪量は増加 し, 煎茶品質も向上した。

4）秋季の䇪素濃度を $36 \mathrm{mg}$ まで高めても，秋冬季に おける成葉の全窒素含有率は高息らかった。一方春季 の場合は $24 \mathrm{mg}$ に高めることによって秋季の窒素濃度に 関係なく新芽の開葉に伴 5 成葉の全窒素含有率の低下は 緩慢で，一番茶のタンニン含有率は低下する傾向を示し た。むた各茶期の新芽の全窒素含有率は土壤中の窒素濃 度が高い将ど多い傾向を示した。

5）以上の結果から，火山灰茶園土袞に扣ける最適の 窒素濃度は, 乾土 $100 \mathrm{~g}$ 当り秋季では $12 \mathrm{mg}$, 春季では $22 \mathrm{mg}$, 夏乎では $30 \mathrm{mg}$ 程度と推測された。

この試験を実施するに際し，御協力をいたたいいた鹿児 島県茶業試駼場の職員および 実習生の皆様に染く感謝す る。

\section{5 引用 文 献}

1）河合制吾，石垣幸三，岡本暢夫：茶技研，No. 9，
40 42 (1953).

2）石垣幸三：茶陚研報，No. 14，1～152（1978）。

3）中西敏雄, 柳井利夫：高知県農技研報，No. 8 , 50 59 (1976).

4）森田敏雄：農及園，49，51～52（1974）。

5）前原三利，袴田勝弘：茶技研， No. 47，100 118 (1974).

6）前原三利，袷田勝弘：茶技研，No. 49，89 104 (1975).

7) 前原三利, · 榇田勝弘 : 茶技研, No. 50, 49 62 (1976).

8）茶試化学研労室 : 茶試研報, No. $6,167 \sim 172$ (1970).

9）G.J.ムーディ, J.D.R. トーマス（宗森 信，日 色和夫共訳）：イオン選択性電極，共立出版（東 京), 17 34 (1977).

10）保科次雄, 否西修治, 石垣幸三：茶技研, No.54, $33 \sim 36$ (1978).

11）小西茂毅，太田 充，岩瀬文夫：土肥誌，49， 221 225 (1978).

12）袴田勝弘, 前原三利：茶研報， No. $48 ， 57 \sim 63$ (1978).

\section{Summary}

In experiment $I$, the optimum nitrogen fertility of tea field soils for tea plants was investigated using three kinds of nitrogen fertility fields of 12,24 and $36 \mathrm{mg}$ per $100 \mathrm{~g}$ of dry soil in autumn to the 3 rd crop season of next year except winter.

In experiment II, each optimum nitrogen fertility of soils in the autumn and spring season for tea plants of the 1st crop was investigated using several nitrogen fertility fields.

1. Over $24 \mathrm{mg}$ nitrogen fertility, the yield, total nitrogen contents of green leaves and qualities of green tea were better than those of usually manured plants.

2. The optimum nitrogen fertility to the 2nd and 3rd crop was $\mathrm{N}-36 \mathrm{mg}$ and it was higher than $\mathrm{N}-24 \mathrm{mg}$ of that to the 1 st crop.

3. The amount of absorbed nitrogen in new leaves of the 1st crop was more increased by raising fertility in spring than in autumn.

About the qualities of green tea, we obtained the same result as the above one.

4. By raising nitrogen fertility in spring to $24 \mathrm{mg}$ total nitrogen contents of old leaves de- 
creased gradually with the growth of new shoots of the 1st crop and tannin contents of new leaves of the 1st crop also decreased.

5. The conclusion is that the seasonable optimum nitrogen concentration in tea fields is about
$12 \mathrm{mg}$ per $100 \mathrm{~g}$ dry soil in autumn, about $22 \mathrm{mg}$ in spring and about $30 \mathrm{mg}$ in summer, respectively.

(Apr. 28, 1980) 